\title{
THE BODY OF HURT IN MARGARET ATWOOD'S NOVEL BODILY HARM
}

\author{
Avital G.Cykman* \\ Universidade Federal de Santa Catarina \\ Florianópolis, SC, BR
}

\begin{abstract}
This article analyses Margaret Atwood's novel Bodily Harm (1981) in regard to its exploration of the link between corporeality and contextuality, focusing on the relation between the historical and socio-cultural context in which identity is constructed and the female character's perception of body and self. The study approaches the character's retrospective journey as a basis for a deconstruction of the character's values, behavior, relationships, and discomfort with the body, revealing the power relations and social causes related to her present situation. The study focuses on the literary articulation of the problems of being female, the exploration of the relation between the biological body and the cultural concept of the body, and the criticism of social representations of women.
\end{abstract}

Key words: Female body; corporeality; contextuality; Margaret Atwood; gender.

\section{Resumo}

Esse artigo realiza uma análise do romance Bodily Harm (1981) (Dano Corporal) escrito por Margaret Atwood, a partir do estudo da ligação entre a corporealidade e a contextualidade. Em especial, observa-se a relação entre o contexto histórico e sociocultural no qual a identidade é formada e a maneira como a protagonista percebe o corpo e a si mesma. Além disso, aborda-se a viagem retrospectiva da protagonista como fundamento de uma desconstrução de seus valores, comportamento, relações sociais e desconfortos com o corpo, revelando as relações de poder e as causas sociais relacionadas à sua situação. O estudo centra-se na articulação literária e nos temas principais acerca dos problemas de ser mulher, na análise da relação entre o corpo biológico e o conceito cultural do corpo, e na crítica das representações sociais de mulheres.

Palavras-chave: Corpo feminino; corporealidade; contextualidade; Margaret Atwood; gênero.

\section{Introduction}

The attention to the body, especially to the way the female body is perceived and how this perception affects women's lives, lies at the heart of Margaret Atwood's novel, Bodily Harm (1981). No wonder that, when interviewed by Elizabeth Meese, Atwood commented:
The body concept has always been a concern of mine. [...] I think that people very much experience themselves through their bodies and through concepts of the body which get applied to their own bodies, which they pick up from their culture and apply to their own. (104)

Indeed, Atwood's work adds to the literary representation of corporeality, or rather, the material,

\footnotetext{
* Avital G.Cykman is a PhD candidate at the Federal University of Santa Catarina. Her work about feminist postmodernism in Margaret Atwood's novel Cat's Eye won first place in the graduate essay contest category in Margaret Atwood Society Awards and was published in the Margaret Atwood Society Magazine, Canada. Her article about anger in Margaret Atwood's novel The Handsmaid's Tale has been published in Arthemis, an interdisciplinary magazine for research in gender, feminism, and sexuality. Her fiction book Life In, Life Out was published in the USA in 2014 to a favorable critical review. Her research interests include corporeality, gender, minorities, women writers and creative writing. Email: avital.gc@gmail.com.
} 
social, and cultural experience of the body, involving bodily physical, emotional, and mental functions in their interconnection with the world. By including the female body in her exploration of women's experience, she has weighed in against the canonical literature and other sources of knowledge that have ignored the female body and avoided its self-representation. Consequently, the study of Bodily Harm reveals how the historical and socio-cultural context in which female characters are constructed affects the characters' perception of body and self. The novel disputes the historical notion of hierarchical dichotomies in which women are associated with nature and with the body, while men are connected to culture and mind.

In view of that, this article seeks to address questions raised by feminist literary criticism in relation to the bond between the female body's corporeality and identity in Bodily Harm. The article depicts female body-related discomfort rooted in social relations, based on the representation of the main character and her experience of the body in the novel. In addition, the article analyzes sources and significance of women's relationships to and through their bodies, based on conventions and practices regarding the female body within the frame of a patriarchal society, as portrayed through the experiences of the female protagonist. The analysis points out gender-related problems and their impact on the way the protagonist deals with the body. While doing so, the study also focuses on the relation between body and writing, and how the female body appears in the text, displaying the physical uniqueness of the body and its part in the unity of the self.

The theoretical framework includes works of feminist literary criticism and theory by Judith Butler, Elizabeth Grosz, and Susan Bordo, with an emphasis on poststructuralist theory and its concept of deconstruction. Judith Butler is one of the way-openers in matters of poststructuralist gender studies. In her book Gender Trouble, Feminism and the Subversion of Identity (1990) she questions the bond between biological sex and gender. Like Simone de Beauvoir and Michel Foucault she argues that it is necessary to perform a deconstruction of every historical pattern and concept introduced as universal truths, in order to reveal the power relations behind them. She also develops the notion of performativity, which she considers necessary since, "The action of gender requires a performance that is repeated" (178).

In her book Bodies that Matter: On the Discursive Limits of Sex (1993) Butler replies to the feminist thinkers who accuse her of deserting the material in favor of ethereal ideas. She argues that only discourse can define the body as a matter existing beyond discourse since the only way to reach the matter beyond discourse is through discourse itself. In her 2004 book, Undoing Gender, she also deals with the possibility to make a difference outside the academy. In her view, social transformation must involve collective action and shared experience. However, certain nuances and personal ways of action are constituting acts in the same way social sanctions and prohibitions constitute society. Therefore, a change can start with deconstruction since this type of investigation makes is possible to identify the breaking points in the tie of power and knowledge, thus raising its intelligibility.

Elizabeth Grosz takes another stand regarding the question of gender in her book Volatile Bodies (1994.) First, the scholar argues that Descartes has set the basis for hierarchy and complete separation between the alleged opposites in Western thought, thus undermining the situation of women. His binary division of body and mind, nature and culture, divine and earthy, and women and men determines the masculine as a divine, productive power identified with the mind, and the feminine as a reproductive but unproductive earthy passive potential identified with the body (6-11). In order to stay out of this course, Grosz rejects the concept of gender altogether and, instead, focuses her analysis on the female body and its place in the determination of the situation of women. In her view, the variance among bodies, differences that mold experience and identity, are not limited to the division between female and male, but include differences of race, class, history, bone structure, and other factors. Therefore, she endorses the concept of the lived body, a body in a situation, coined by Beauvoir. It is a phenomenological notion: "to be present in the world implies strictly that there exists a body which is at once a material thing 
in the world and a point of view towards the world" (39). Her determination that the body should be read contextually, in its socio-cultural, historical situation, however, is not different from Butler's, and goes hand in hand with Susan Bordo's view.

Bordo writes about the female body in Unbearable Weight: Feminism, Western Culture, and the Body (1993) as the site on which political power is exercised and abuse is performed. She analyses Butler's and Foucault's theories, and instead of trying for a general theory like them, she chooses to focus on body disorders such as anorexia and bulimia as examples of the body as a cultural text, and a direct center of power relations. The disorders illustrate the extreme nature of the treatment of the body under social and historical pressures. In this way, she brings female body experiences into feminist discourse. She writes,

Many see the body both as a living cultural form and as a subject of scholar theorizing - as a significant register of the fact that we are living in fragmented times. Our cultural attitudes toward the body are full of dissonances, expressive of the contradictions of our society. On the one hand sex has become deadly; on the other hand it continues to be advertised as the preeminent source of ecstasy, power and selffulfillment. (288)

Both Butler and Goffman, she argues, have been fundamental for our understanding that "we learn how to fabricate and manipulate language $[\ldots]$ through imitations and learning of cultural idioms" (289). However, according to her, a potential resistance to gendered definitions may lead to a preservation of the status-quo. In order to focus on the body, Bordo leans on Foucault's theory, according to which politics, commitment, and the desire for change act on the body, the passive body, through the organization of the subject's life. The body is tamed, designed, and influenced by multiple historical images of the self, femininity, and masculinity. It has become a subject of external dominance, and of the consequent quest for transformation and improvement. She points out that there is no advantage in defining men as the enemy, in that relation, since they too have been trapped within the same social order. She mentions, however, that there are still men in powerful positions who act upon their interest to block women's opportunities in positions requiring a rational, intellectual, and responsible capacity.

Despite the controversy over the concept of gender and its abstraction, these feminist thinkers share common ground according to which as long as the field of differences is taken into account where the female body is studied, the body will not determine an identity in the historically narrow concept of binarism.

\section{The Body of Hurt in Bodily Harm}

Bodily Harm parades the character's whole life through her past and present points of view, setting different layers of issues concerning the body. The novel opens with Rennie Wilford, a young woman living in Toronto, Canada, and working as a lifestyle journalist. Rennie lives on the surface of things and avoids any emotional or ideological involvement as much as she can. Feminism is one of the matters she has previously considered important but now sees as irrelevant. She feels secure in her steady job and relationship and is certain that she, like all women, is now in control of her life. However, the discovery that she suffers from breast cancer shakes her certainty that her life has turned out the way she intended. Thus, her sicknessgenerated crisis provokes a reconsideration of past choices and overlooked conflicts. As she looks back at her life, she turns her attention to her body experience and notions. This mental journey is regarded, for the scope of this work, as deconstruction. It refers to the process of an individual's examination of history outside the patterns of essential or intrinsic meaning, started in order to observe the factors that constitute it and construct new meanings.

The story spirals from the acknowledgement of a death-threat-breast cancer-to the surgery and to the life changes that follow. Principally, the introduction of a certain physiological aspect of this bodily harm, the illness, sets the ground for a further examination of what bodily harm means. The novel explores a range of bodily harms that interact with one another in 
interconnected stories, revealing an interplay between micro and macro power relations. The protagonist's malignant tumor and the life-threatening nature of her illness form a connection to what she defines as a malignant behavior of people. Such connection is implied, for instance, when a dangerous intruder settles in her apartment the way the sickness has invaded her body. Both malignant subjects are expelled, but they lurk in the abyss and may return. In fact, "She has been turned inside out, there's no longer a here and a there" (290). The patterns are similar in all spheres.

In the process of deconstruction, Rennie's rigid upbringing in Griswold, Ontario, a small town in Canada, her cold relationships with the women of her family, and her personal and professional interactions with men come into play. The readers find out how the social and historical context of her past interactions determines her reaction to the mutilation caused by the operation, and how this influence has caused her continued detachment from her body. The crisis propels the character not only toward self-reflection but also toward change and dislocation. She takes on a writing assignment for a journal's tourism section and travels to a Caribbean island on which she ends up imprisoned as a spy. Here, her own story becomes intertwined with other stories of bodily harm. Once in prison, she witnesses the lasting effect of oppression and brutality upon her cellmate Lora. Her initial disbelief, sense of superiority, and cynicism toward Lora disappear as she notices Lora's integrity and passion. She also realizes that neither she nor Lora, or other women, are exempt from oppression. Both of them suffer violence from their jailers because they are easy targets. Now, the story of the unrelenting violent political struggle intersects with theirs. Toward the end of the novel, Rennie's intimacy with pain helps her recognize other forms of suffering and bestows her with a new capacity for compassion. She tries to help Lora survive a brutal attack, and, in a parallel process of regaining power, decides to speak up and take responsibility for the fate of the oppressed people on the islands.

The novel deals with the body as a site on which political power is applied and abuse is exercised. It brings about a range of related themes including "the gaze", or rather, the active application of social surveillance and its implications on body and identity, modes of negation such as detachment, the binary division between body and mind, and victimization.

In the beginning of the 1980's, the period in which the novel is written and published, the influence of postmodern theories brings a certain shift from the feminist interest in the body toward the related issues of gender and identity. Accordingly, as the narrative develops, the effect of poststructuralism appears in the changing bodily notions of the protagonists and the fragmentary nature of their identity. Rennie's journey into the past reveals how her identity has been formed across time and space and over multiple discourses. As a result, the protagonist discovers the mechanism that stands behind gender stereotypes and the meanings attributed to female bodies.

\section{The Flawed Body}

Rennie's writing about herself and her reality expresses her constant anxiety in regard to the body. One of the principal factors in her discomfort and her later sense of inadequacy is the imperfect, flawed body, or rather, the burden of a body type existing out of socially accepted standards. In that line, according to Foucault, women have become the slaves of their body-maintenance due to social pressures that push them toward a constant process of self-improvement. In Discipline and Punish the philosopher describes constant surveillance as the central technique of the disciplinary power. Directed toward disciplining the body, first, it then takes over the mind and induces a psychological state of "conscious and permanent visibility" (201). Bordo (1993) endorses his contention that the body is the primary site of power in modern society, using it as the basis for her analysis of the social control of women through their bodies and sexuality.

\section{Health}

All her life Rennie has tried to prevent any straying from the standard and control the body, to no avail. Therefore, having the sense of permanent 
visibility in mind, it is conceivable to see her presurgery systematic caring for her body's fitness, weight, health, and beauty as a surrender to discourse. While healthy, she has taken care of her body maintenance and nourishment, believing in the importance of a perfect body for her well-being, attractiveness, and social acceptance. Her behavior reflects Bordo's theory that women have developed complicity with patriarchal standards of femininity. According to the scholar, the association between power through surveillance-and the internalized gaze-with a fatal bodily practice (such as anorexia) is an illustration of the link between the disciplinary power and the social control of women. Rennie wants to take control over her body, in order to perfect it, and by doing so she enslaves herself.

After the surgery, when the physical pain caused by the unilateral partial mastectomy is over, Rennie feels damaged because her body is damaged. In fact, she remains with a minor physical harm if compared to a tumor: a lacking part of her breast and the scar over it. However, she is afraid that it will repel men and diminish her chance of having or finding love, a highly desired objective for her. Already on the night before the surgery, knowing that she is sick and going to be mutilated, her thoughts betray her self-defying attitude: "She could understand his [her companion Jake's] shock and disgust and the effort he was making in order not to reveal them, since she felt the same way" (21). Consequently, the text dealing with the body, coined corpotext for the scope of this work, about the night before the surgery reveals her distancing from body sensations, as if any sensation would be painful, intruding, obligatory and even belittling. It is a turning point:

She used to like it when he slid into her wet like that, but tonight she was only waiting for a certain amount of time to be over, as if she were at a dentist's office, waiting for something to be done to her. A procedure. [...] Her body was nerveless, slack, as if she was already under the anaesthetic. [...] At last she faked it. That was another vow she'd made once: never to fake it. (21)
After the operation, she seeks Jake's sincere acceptance but is certain that his sincerity will only reveal a rejection of her body, and based on it, of her. She is unaware or uncritical of her own feeling that the sickness has affected her whole self, damaging much more than her physical body. So far, she has not questioned the meaning of her self-defining as "damaged". Consistently in line with her feelings, the corpotext discloses her vulnerability by revealing the subtleties of her new body language: "Despite the heat Rennie lies with her arms folded, left hand on her breast, right hand on the ridge of skin that slants across the side of her breast up towards her armpit. This is how she always sleeps now" (48). This and other breaks in the text come to illustrate her sense of fear and of fragile hope. The ridge of the skin gains its independent power through the active tense. It is not slanted; it slants.

Rennie's new state of mind goes on to affect her relationship with her female friend Jocasta, as well, since Rennie expects sincerity without pity, and understanding without inquiry, and this turns out to be impossible. She finds that "Jocasta was a little too surprised to hear from her, a little too pleased" (163)". Afterwards, Rennie needs to make an effort to keep meeting her friend, since she sees her own damage, her wound, reflected at her from Jocasta's caution.

Metaphorically, the wound opens a window into Rennie's depths, offering her an opportunity to deal with her self beyond the surface and reconnect with her own vulnerability and power. In fact, although she has been educated to respect superficial codes, she has never approved of them wholeheartedly. Despite her lifestyle writing, a shallow venue for her talents, in her view any shallow way of living represents her resented hometown, the conservative Griswold, where "Surfaces determined whether or not people took you seriously" (26). The following corpotext conveys a possible new insight in a literal, physical way: "She runs the fingers of her left hand over the skin of her left breast, the good one, the one she hopes is good, as she does every night. From the surface you can feel nothing, but she no longer trusts surfaces" (48). However, while she is finally ready to take the emotional journey into her depths, she suspects that men may look at the surface 
alone and reject her. The scar, therefore, represents both seeing and being seen. The gaze involved is judgmental.

\section{The gaze}

Beauvoir has diagnosed the way women-such as the protagonist-live their bodies as objects for the gaze of others, a phenomenon that is not originated in anatomy but in "education and surroundings" (307). Rennie's worry about being seen and "found out" acquires new meanings due to sickness. It is affected by her current fear of a new diagnosis, or rather, a view of her depth that will announce an upcoming early death. She reiterates that she is in remission, and not recovered. The doctors, she says, tell her they will always need to keep an eye on her. They, too, will always look at her through her wound, reminding her of her fragility in the face of mortality, and emphasizing her weakness. This medical gaze takes a personal turn when Rennie falls in love with the surgeon who has operated on her, a married man. She rejects his gaze even if he is to become a lover: "She wanted to see him lying with his eyes closed, she wanted to see him and not be seen, she wanted to be trusted" (195). She craves his love but suspects that in his situation as a married man his love cannot transcend the circumstances. More than that, she is afraid that he will always see her as a woman in need, since he knows, without telling her, that she is dying. This dread, a self-imposed obstacle, impacts this relationship, as the image of herself as weak and needy, a classic view of women in a sexist society, is a characterization she tries to avoid.

Her insecurity makes her wonder if she has ever accepted her self beyond the body surface. As far as she can see, before the operation and as long as her body has been healthy and unmarked, she lived in peace. With the change in the body's situation, however, her self-confidence collapses. Her self-esteem, it appears now, has been based on the response to the body's message of fitness, sexuality, and aesthetics. Hence, her satisfaction has depended on the way others have perceived her through her body. It is likely that her present suffering is the result of her internalized social expectation of an "adequate body." This phenomenon is articulated by Bordo:
And for women, associated with the body and largely confined to a life centered on the body (both the beautification of one's own body and the reproduction, care, and maintenance [...], culture's grip on the body is a constant, intimate fact of everyday life. (17)

Another expression of the gaze, mirrors, appears in the novel, reflecting much more than physical bodies. The protagonist gazes at the mirror reflection through the prism of the conceptual body, always finding her image lacking or unclear. In her shame of her mutilated breast and her fear of the meaning it may have for her life, Rennie prefers to steer clear from mirrors. Still, she finds herself observing her reflection once and again. John Berger, cited by Atwood in the epigraph of Bodily Harm, points to the tradition of the mirror motif as a symbol of female vanity, and adds that "the real function of the mirror [...] was to make the woman connive in treating herself as, first and foremost, a sight" (51). He defines checking the mirror as a compulsion:

\begin{abstract}
A woman must continually watch herself. She is almost continually accompanied by her own image of herself. Whilst she is walking across a room or whilst she is weeping at the death of her father, she can scarcely avoid envisioning herself walking or weeping. (46)
\end{abstract}

Another aspect of the impact of surveillance on the protagonist is her surrender to her companion's design. Rennie lets Jake design and redesign her, take over her body, and invent an identity for her. She remembers how "He liked buying her things like that. Bad Taste. Garters, merry widows, red bikini pants with gold spangles [...]. The real you, he'd say, with irony and hope" (20). She leaves her body in the arms and control of her lover and finds ways to depart from this disturbing place. In the end, the surveillance mechanism and the selfsurveillance become both the origin and the definition of her sense of self.

\section{Gender roles}

In a general manner, Rennie has obeyed genderrelated expectations and taken on stereotyped gender roles 
in her personal and professional life. Upon her separation from Jake, she traces the link between her living for and through her partner's gaze to her lifestyle journalism. Both her editor and Jake have expected a passive acceptance of roles that are gender-based stereotypes, since it has served their needs, and in her will to please them, she has collaborated. In her job, she has agreed to write lightly about serious issues like porn, and seriously about light matters like celebrities. Her previous disapproval of this type of writing has worn thin, except in sporadic bursts of disgust. She recalls the editor's complaint that radical women's magazines miss the "element of playfulness" in pornography, and his instruction to capture the play. Customarily, Rennie obeys, but she feels sick in front of the dehumanizing exhibition items. When she sees a work showing rats coming out of a vagina, she leaves in such fright that it impacts the way she sees Jake. It relates to the fact he hangs on the wall pictures of women with exposed bodies, and with heads like door knobs, and prefers sexual games of domination. His behavior reflects the same idea of lightheartedness when aggression is involved. Naturally, as she expresses her discomfort about the relation between what she saw and his imitations of rape, Jake belittles it. Nevertheless, such occasions of epiphany become the most significant turns in her perception. She realizes with certain regret that she has lived according to a less than demanding worldview, adopting light existence as a living philosophy. As the struggle against her breast cancer unfolds, her life stands to a test and her previous satisfaction in her situation vanishes. She is beginning to discover that her denial of depth has affected her identity and blocked her away from life.

Butler's analysis of power relations is a tool for understanding the causes of Rennie's subordination. Mostly, the explanation is not based on the traditional model of power since it is an oversimplified conception of power relations and victim-victimizer roles. Instead, drawing on Foucault, she says that women's experiences, self-perception, conduct, and abilities are constructed by localized forms at the political micro-level. Power is exercised rather than possessed, and it circulates through society by a general repetition of acts. In Bodies that Matter she says:
[...] this repetition is what enables a subject and constitutes the temporal condition for the subject. This iterability implies that "performance" is not a singular "act" or event, but a ritualized production, a ritual reiterated under and through constraint. (95)

In accordance with this theory, Rennie hasn't been aware of the extent to which these pressures have molded her choices. Now she realizes that despite the apparent open-mindedness attributed to Toronto, the city to which she has escaped from her conservative hometown, most people still repeat the same models. Her compliance shows the strength of the construction.

\section{The lived body}

The sections above point to the "lived body" experience, as the protagonist goes through constant change, and alters her perception of her self, and her relationships. Drawing on scholars such as Beauvoir, Moi, and Grosz, the present analysis reads the body through its physiological and psychic situation, and any change in its condition modifies the protagonists' situation in the world, and shapes their identity. Rennie's weak body and pronounced vulnerability scare Jake and transform his attitude from playful and somewhat vicious to serious and forced. The change also evokes care on the surgeon's part, facilitating the doctor/patient type of affair, and finally terminating it. In another situation, Rennie believes that she can silence the police officers who hint that her sexual presence has drawn a stalker, by showing them her mutilated breast. It is her (initial) belief that after the operation she cannot be seen as a sexual being.

In these episodes, her own reaction to the change in her body and to people's response to the change mobilizes the situation. In her personal relationships, she cannot separate people's reaction to her illness or scar and their affection for her as a person. Hence, she corresponds to the difference in people's (alleged) views of her bodily situation and questions their sincerity and love. Simultaneously, she finds that dealing with her current fears and needs requires a readjustment of her worldview. She starts her adaptation to the 
new situation while still with Jake. The paralyzing impact of her body's change on their relationships is a clue to the fragile fundaments of their connection. Possibly, her own perception of the body's role in their relationship makes her insecure in regard to his love. The communication between them is broken, and their sexual relations become null, as this exchange reveals:

You're using me as a Teddy Bear, Jake said. Why don't you go back to sucking your thumb? [...] Sometimes I think you don't like me very much, she said. Like, he said, Is that all you want to be? Liked? Wouldn't you rather be passionately and voraciously desired? Yes, she said, but not every night. (101)

He makes an effort to stay despite his aversion to commitment, but according to him, she is relentless in putting her sickness in the center of their relationship. To this, she replies, "Why? [...] Because I don't feel like it in the same way any more? Because I don't believe you do either?" (102). She considers his efforts an obligation and not his wish. In her opinion, Jake is mostly interested in the way she looks, acts, and plays into their sexual games and not in her thoughts and emotions. It becomes apparent that the growing distance is a result of a mutual discomfort, and not only his. They draw apart, and he ends up leaving.

Even before the end of their relationships, Rennie already goes on seeking approval from another man. She relates to Daniel, the surgeon, a man who has not only seen her harmed breasts, but has disfigured them in order to save her. He is not a man of surfaces, and he is connected to the body of hurt and its depth of emotion. However, she suspects that he is interested in her not because he is attracted to who she is, but because he is a caretaker. Again, she doesn't ponder the possibility that her sickness, this new bodily situation, may not be a fundamental element in his consideration of her as a lover.

\section{Detachment and binary division}

In addition to its aforementioned effects, the repressing gaze also touches upon the theme of detachment and of binary division. The detachment of Rennie from denied, repressed, or abandoned parts of her life and identity is present in her distant relation to her bodies. All the elements, including the body, are inseparable from the self, and therefore she has become tortured and lost. Atwood has described a similar kind of detachment in Surfacing, where the unnamed main character expresses the feeling that her head is separated from the rest of the body. The author's criticism of the division endorses the postmodern view of identity in the sense of a split and creates a hierarchy between oppositions. Feminist thinkers such as Butler and Grosz have examined the concept of binarism, or dualist thinking, in the light of alleged oppositions such as body and mind, men and women, nature and culture, and evil and goodness. The detachment of the character from her body displays her own binary notion of the world. Rennie tends to maintain a body/ mind split in order to avoid suffering, but by doing so she disconnects herself from being fully awake and alive. Only when she rejects this split, embarking on a journey of self-discovery in which there are no fixed boundaries, does she come to terms with her unified, however fragmentary, identity.

Before the journey starts, however, Rennie isn't aware of the subjugated roles of sexuality responsible for her situation. She doesn't deny herself physical satisfaction, but she cannot identify with the body's urges, so she separates her emotions from her physical pleasure. This negation of physicality is an attempt to keep identity within the patriarchal policing norms she has known since childhood. As Kristeva says, "at the center of the Christian ideal of womanhood, the woman's body appears as a sealed vessel. The tightly sealed bodily borders place the body beyond the obscene" (71).

In the beginning of Bodily Harm, Rennie is already an observer of life, deliberately living at the level of "surfaces" and "appearances" (26). The split is rooted in her conservative education, in which any expression of physicality or impulsive behavior has led to punishment. Furthermore, the shapeless clothes of the women in her family and their controlled gestures have implied that the body with its desires and animalistic features is 
shameful. This kind of education alludes to Aristotle's separation of body and mind. In Rennie's family, the body is considered to be a deviating entity over which the mind has to be in control. Although theoretically she hasn't adopted the rejection of physicality, and has even left her hometown, looking for liberation, she still treats her body as if it were a subjugated object she occupies uses, maintains, and enjoys. Stripped from other signification of the self, or what she considers to be the self, the body is defined as a mere physical entity, and thus, she objectifies it. As a result, she does not question its objectification by Jake, but considers his sexual games and his attempts to create an image for her harmless. Like him, she observes her body's animalistic and aesthetic privileges with an amused and distant nod. Another sign of her detachment appears when she becomes sick and feels as if her body is a machine that broke down. She becomes angry with the body, as if it's a traitor and not a part of her:

The body, sinister twin, taking its revenge for whatever crimes the mind was supposed to have committed on it [....] She'd given her body swimming twice a week, forbidden it junk food and cigarette smoke, allowed it a normal amount of sexual release. She'd trusted it. Why then had it turned against her. (82)

The split returns in the pre-surgery scene, that acts in both the literal and metaphorical way, as she says, "she can see everything, clear and sharp, under glass, her body is down there on the table [...] she wants to rejoin her body but she can't get down" (172-73).

\section{Conclusion}

The exploration of the body of hurt in Bodily Harm has revealed that Rennie's detachment is a symptom of her insecurity and fear of suffering. It is another aspect of surrender to social surveillance, much like her compliance with gender roles. Her detachment involves distrust in her body, due to the meanings the body may carry. It becomes obvious that the gaze of others has made her self-conscious. She checks herself in the mirror or otherwise and tries to adapt the way she looks, moves, dresses, and acts to external expectations. Clearly, she gives up on the flow of life as she blocks it, and therefore, she lives on the surface, unaware of her needs.

When Rennie finds that she no longer fits within Western culture's image of a "normal" woman, whose body is adequate, she reaches the dead-end of social acceptance as she understands it. The positive result of it, as Atwood illustrates, is the internal journey she starts when she believes she has no other options. In her moments of crisis, she wishes to connect with the flow of life but realizes that it requires a complex study of her history. As she goes back into her childhood, she identifies certain sources of her identity. The education given by rigid institutions of a patriarchal order has been a principal factor in her constraint. The behavior of most of her family and friends at that time has been affected by these values, thus becoming an oppressive tool of the same order. The bodies of girls are denied their impulses and natural activity, and they grow up, becoming estranged from it. When it subsequently becomes the focus of interest of men, and the basis of relationships in which men are controllers, the gap between the character and her body deepens. Rennie embarks on intense sexual relationships, but these are not a sign of unity with the body. She separates herself from it, and thus, separates herself from the relationships, and the emotional connection becomes lacking. Gradually, Rennie understands her own complicity with the social order. The deconstruction aids her in revealing the reasons for her current dissatisfaction, distance from life, behavior, situation, and feeling of loss.

\section{Aknowledgements}

I would like to offer my gratitude to my MA and $\mathrm{PhD}$ supervisor Susana Bornéo Funck for sharing her vast knowledge and her insights and for encouraging me to do the best I can always.

\section{References \\ Primary Sources}

Atwood, Margaret. Bodily Harm. Toronto: McClelland \& Stewart, 1981. 


\section{Secondary Sources}

Aristotle. Physics. Trans. R. P. Hardie and R. K Gaye. Greece, 350 B.C.E. Classics. M. I . T. Web. 1 Nov. 2012. http://classics.mit.edu/Aristotle/ physics.2.ii.html.

Atwood, Margaret. Cat's Eye. London: Bloomsbury, 1989. .Surfacing. 1972. London: Virago, 1979.

. Survival. Toronto: McLelland and Stewart, 1972.

Beauvoir, Simone de. The Second Sex. 1949. transl. H. M. Parshley. New York: Vintage, 1989.

Bouson, JB. Brutal Choreographies: Oppositional Strategies and Narrative Design in The Novels of Margaret Atwood. Massachusetts: Massachusetts UP, 1993.

Bordo, Susan. Unbearable Weight: Feminism, Western Culture, and the Body. Berkeley: U of California Press, 1993.

Butler, Judith. Bodies That Matter: On the Discursive Limits of Sex. New York and London: Routledge, 1993.

Gender Trouble, Feminism and the Subversion of Identity. London: Routledge, 1990.

.Undoing Gender. New York: Routledge, 2004.

Davis, J. Lennard. Enforcing Normalcy: Disability, Deafness, and the Body. New York: Verso, 1995.

Foucault, Michel. Discipline and Punish: the Birth of the Prison. 1975. trans. A Sheridan, London: Penguin, 1977

Fuss, Diana. Essentially speaking: Feminism, Nature and Difference. New York: Routledge. 1989.

Grosz, Elizabeth. Volatile Bodies: Toward a Corporeal Feminism. Bloomington: Indiana UP, 1994.

Jong, N.D. "Mirror images in Margaret Atwood's Cat's Eye." Nora: Nordic Journal of Women's Studies, Volume 6, Number 2, 15 Sep. 1998: 97-107.

Kafka, Franz. "A Hunger Artist." The Metamorphosis and Other Stories. 1924. Trans. Ian Johnston. Nanaimo BC: Malaspina University-College, 2013. https://records. viu.ca/ Johnstoi/kafka/hungerartist.htm

Kristeva, Julia. “Women's Time.” Feminisms. Eds. Robyn R. Warhol and Diane Price Herndl. New Brunswick: Rutgers UP, 1991. 443-59.

Meese, Elizabeth. Crossing the Double-cross: The Practice of Feminist Criticism. Chapel Hill: University of North Carolina, 1986.

"An Interview with Margaret Atwood." Black Warrior Review 12 (1985): 88-108.

Moi, Toril. "What is a Woman? Sex, Gender, and the Body in Feminist Theory." What is a Woman?: And Other Essays. New York: Oxford UP, 2000. 3-121.
Plato. Phaedrus. Trans. Benjamin Jowett. Greece, 360 B.C.E. Classics. M.I.T. Web. 1 Nov. 2012. http://classics. mit.edu/Plato/phaedrus.html.

Shahar, Galili. "How the Body is Written". Http://glz.fm/ index.php? action $=$ media;sa $=$ album;in=94, Tel-Aviv. 1 Nov. 2012. Lecture.

Tolan, Fiona. Margaret Atwood: Feminism and Fiction. Amsterdam: Rodopi, 2007.

Weedon, Chris. Feminism, Theory, and the Politics of Difference. US: Wiley-Blackwell, 1999.

Woolf, Virginia. A Room of One's Own. 1929. http:// gutenberg.net.au/ebooks02/0200791.txt.

Young, Iris Marion. On Female Body Experience: "Throwing Like a Girl" and Other Essays, New York: Oxford UP, 2005.

Recebido em: 25/05/2015

Aceito em: 17/08/2015 